\title{
PCR detection of Mycobacterium paratuberculosis in Crohn's disease granulomas isolated by laser capture microdissection
}

\author{
P Ryan, M W Bennett, S Aarons, G Lee, J K Collins, G C O'Sullivan, J O'Connell, \\ F Shanahan
}

Gut 2002;51:665-670

See end of article for authors' affiliations

Correspondence to Professor F Shanahan Department of Medicine, Cork University Hospital, Cork, Ireland; email:

f.shanahan@ucc.ie

Accepted for publication 30 April 2002

\begin{abstract}
Background and aims: The uncertainty surrounding the role of Mycobacterium avium subsp paratuberculosis (Map) in Crohn's disease has been compounded by possible contamination from Map present in the lumen microflora. This study used laser capture microdissection (LCM) and polymerase chain reaction (PCR) to detect Map DNA in subepithelial granulomas, isolated from 15 surgically resected, formalin fixed specimens of granulomatous Crohn's disease and from 12 granulomatous disease controls (10 bowel, 2 non-bowel).

Methods: The effect of amplicon size on reliability of PCR from formalin fixed samples was examined by amplifying $435 \mathrm{bp}$ and $133 \mathrm{bp}$ sequences of the human APC gene. After this, nested primers were designed to detect a small fragment (155 bp) of the Map specific IS900 gene in Crohn's granulomas. LCM isolated granulomas from Map culture positive bovine intestine was used as positive control. PCR product specificity was confirmed by direct DNA sequencing.

Results: The smaller, but not the larger, fragment of the APC gene amplified reliably in all samples. Amplification of the 155 bp fragment of the IS900 gene detected Map DNA in microdissected Crohn's granulomas in 6 of 15 cases, and in 0 of 12 disease control granulomas.

Conclusions: LCM can be used to detect Map DNA in granulomas in a proportion of patients with Crohn's disease. However, formalin fixation requires that comparatively short DNA fragments of the Map specific IS900 gene be targeted, to permit consistent detection. Detection of Map DNA within granulomas might suggest an infectious aetiology in a subset of patients; alternatively, a transmissible agent may not be involved but mycobacterial DNA may influence pathogenesis by modifying the local cytokine responses.
\end{abstract}

th n 1895, Johne and Frothingham first described what they thought was a form of atypical tuberculosis in animals with chronic granulomatous enteritis. ${ }^{1}$ The organism involved was subsequently characterised, and is now named Mycobacterium avium subsp paratuberculosis (Map). A potential link between Map infection in cattle and human granulomatous enteritis was first noted in $1913 .^{2}$ Interest was revived in the early 1980s with the report of the isolation of Map from three Crohn's disease patients. ${ }^{3}$ Routine culture from tissues is difficult because when present Map is commonly in spheroplast form (cell wall deficient), which does not thrive in standard culture conditions. ${ }^{45}$ Culture is also time consuming, labour intensive, and has not yielded definitive human prevalence figures, although recent refinements in technique have improved Map detection rates. ${ }^{6}$ It has also proved difficult to detect Map in Crohn's disease tissues by other methods: the microscopical examination of Ziehl-Neelsen stained tissue has low sensitivity and detects all types of Mycobacteria; serology studies have been beset by problems of non-specificity because of antigen cross reactivity, ${ }^{7}$ although more recent studies have reported a specific high immune reactivity to recombinant Map antigens in Crohn's patients. ${ }^{89}$ These difficulties reflect the fact that Map micro-organisms when present in Crohn's disease are few in number, relative to bovine cases of Map infection (Johne's disease).$^{10}$

More recent work has focused on molecular methods to determine the prevalence of Map in cases of Crohn's disease. ${ }^{11}{ }^{12}$ Interpretation of any positive results from studies using molecular methods has been confounded by possible tissue contamination with Mycobacteria from the intestinal lumen, the significance of which is uncertain. In this study we used laser capture microdissection (LCM) to overcome this problem by specifically isolating subepithelial granulomas ( fig $1)$, as it is reasonable to predict that aetiologically relevant bacterial agents should be present within granulomas. ${ }^{13}$

\section{METHODS}

\section{Samples}

Archival samples of surgically resected specimens of granulomatous Crohn's disease were obtained from the Department of Histopathology, Mercy Hospital, Cork. The diagnosis of Crohn's disease was based on conventional clinical, radiological, and histopatholgical criteria. Cases were reviewed by an experienced consultant histopathologist (GL), and 15 unambiguous cases of granulomatous Crohn's disease were selected for study-granulomas were isolated from small bowel in seven cases and large bowel in eight cases. Formalin fixed paraffin wax embedded samples were used in order to recognise granulomas in tissue sections, stained with haematoxylin and eosin (H\&E), before microdissection. Negative control samples were from similarly treated archival samples of nonCrohn's granulomatous tissue samples from gut and non-gut diseases (table 1). In both test cases and controls granulomas were well formed, easily identifiable for microdissection, and not contiguous with fissures or disrupted crypts. However, the

Abbreviations: LCM, laser capture microdissection; APC, adenomatous polyposis coli; PCR, polymerase chain reaction; Map, Mycobacterium paratuberculosis 

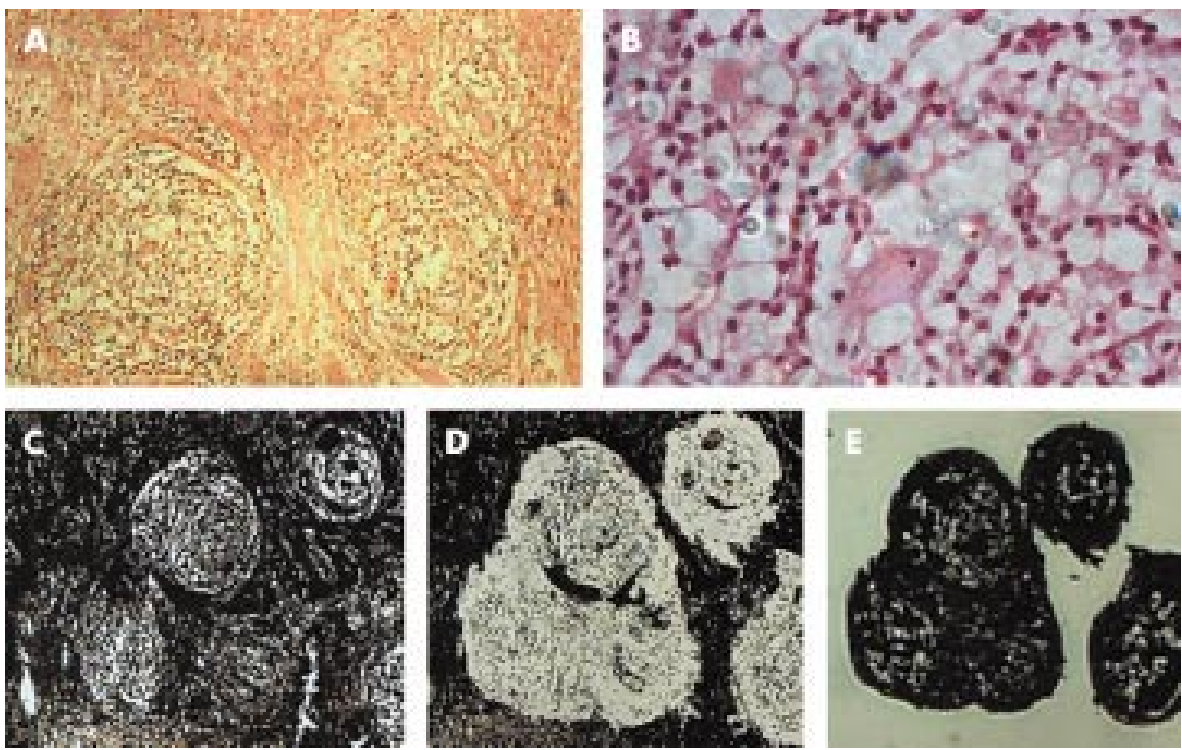

Figure 1 Isolation of subepithelial granulomas by laser capture microdissection. (A) and (B) show low and high power views respectively of the haematoxylin and eosin stained "guide" section of the granulomas to be dissected; (C) deparaffinised section pre-microdissection; (D) the same section after microdissection; (E) captured cells on thermoplastic cap.

density of granulomas in both groups was variable. Positive control tissue was formalin fixed, paraffin wax embedded bovine intestine obtained from the local authority veterinary laboratory, where the animal had tested positive by culture for Map before being put down. Histological analysis of bovine small bowel revealed diffuse inflammation typical of histiocytic Johne's disease, but a few well formed granulomas were easily identifiable for microdissection.

\section{Laser capture microdissection of specimens}

Before microdissection, $5 \mu \mathrm{m}$ thickness tissue sections were cut from the paraffin block and mounted without fixative on uncoated, uncharged slides. The first slide was stained with $\mathrm{H} \& \mathrm{E}$ to determine the position of the granulomas and other tissue landmarks in the section. The next consecutive tissue section was deparaffinised with xylene, dehydrated in a series of alcohol baths, and allowed to air dry until chalky white. Granulomas were then microdissected using the LCM microscope (PixCell II, Arcturus Engineering, CA, USA). This system uses a laser to melt minute areas of a plastic cap, resting on the prepared slide, to target tissue. ${ }^{14}$ When the cap is lifted off the slide, the chosen area of tissue is stuck to the plastic and lifts off with the cap (fig 1). The plastic caps and attached tissue were placed into appropriately sized sterile microfuge tubes to prevent contamination. We also collected corresponding whole cross sections of tissue by fully scraping a third consecutive deparaffinised tissue section from the slide into a separate microfuge tube.

\section{DNA isolation}

DNA was extracted from all tissue samples using DNeasy tissue DNA isolation kit (Qiagen, Crawley, UK) as per manufacturers instructions, and resulting DNA was eluted in $100 \mu \mathrm{l}$ of sterile distilled water and stored at $-20^{\circ}$.

\section{PCR}

To determine how size affected ability to reliably amplify a target sequence from isolated human DNA samples, previously published primers amplifying a large (435 bp) and a small ( $133 \mathrm{bp}$ ) fragment of the APC "housekeeping" gene were used (table 2). ${ }^{15}$ PCR of both fragments was performed on microdissected granulomas and whole tissue sections of Crohn's disease and disease control (non-Crohn's) tissue. An additional round of 25 cycles (total 65 cycles) was found to be necessary to amplify the small fragment reliably in microdissected samples, and this was also done with PCR amplification of the large fragment to permit comparison.

To reliably detect Map, nested PCR systems amplifying large and small sequences of the IS900 gene were compared. IS900 is a multi-copy insertion sequence that has been targeted for PCR amplification in previous studies investigating prevalence of Map in Crohn's disease ${ }^{16-24}$ Primers amplifying a previously published $413 \mathrm{bp}$ sequence, ${ }^{25}$ and newly designed nested primers amplifying a 328 bp fragment were used. Primers were also designed to amplify smaller 193 bp primary and 155 bp nested sequences of IS900 (table 2). The reliability of these

\begin{tabular}{|c|c|c|}
\hline Non-gastrointestinal & $\begin{array}{l}\text { Mediastinal node sarcoidosis } \\
\text { Cholesterol granuloma of breast }\end{array}$ & $\begin{array}{l}\text { Non-caseating granuloma } \\
\text { Foreign body granuloma }\end{array}$ \\
\hline Gastrointestinal & $\begin{array}{l}\text { Diverticular disease }{ }^{*} \times 2 \\
\text { Perianal sinus tissue* } \\
\text { Colon surgical scar* } \\
\text { Tubular adenoma of colon } \\
\text { Adenocarcinoma of colon } \\
\text { Tuberculosis of colon }\end{array}$ & $\begin{array}{l}\text { Foreign body granuloma } \\
\text { Foreign body granuloma } \\
\text { Foreign body granuloma } \\
\text { Foreign body granuloma } \\
\text { Foreign body granuloma } \\
\text { Caseating granuloma }\end{array}$ \\
\hline
\end{tabular}

*Denotes samples of disorders not normally associated with granulomas but in which granulomas were reported on routine histopathological examination. 
Table 2 Sequence specific primers and their reaction conditions

\begin{tabular}{|c|c|c|}
\hline Target sequence & Primers & Reaction conditions \\
\hline $\begin{array}{l}\text { APC gene } \\
435 \mathrm{bp}\end{array}$ & $\begin{array}{l}\text { 5'-AAGCCTACCAATTATAGTGAACG-3' } \\
\text { 5'-AGCTGATGACAAAGATGATAATG-3' }\end{array}$ & $\begin{array}{l}95^{\circ} \mathrm{C} \text { for } 15 \mathrm{~min} ; 65 \text { cycles }(40+25) \text { of } 94^{\circ} \mathrm{C} \text { for } 1 \mathrm{~min} \text {, } \\
58^{\circ} \mathrm{C} \text { for } 1 \mathrm{~min}, 72^{\circ} \mathrm{C} \text { for } 1 \mathrm{~min} \text {; and } 2 \mathrm{~min} \text { at } 72^{\circ} \mathrm{C}\end{array}$ \\
\hline $\begin{array}{l}\text { APC gene } \\
133 \mathrm{bp}\end{array}$ & $\begin{array}{l}\text { 5'-GGA CTACAGGCCATTGCAGAA-3' } \\
\text { 5'-GGCTACATCTCCAAAAGTCAA-3' }\end{array}$ & $\begin{array}{l}95^{\circ} \mathrm{C} \text { for } 15 \mathrm{~min} ; 65 \text { cycles }(40+25) \text { of } 94^{\circ} \mathrm{C} \text { for } 1 \mathrm{~min} \text {, } \\
55^{\circ} \mathrm{C} \text { for } 1 \mathrm{~min}, 72^{\circ} \mathrm{C} \text { for } 1 \mathrm{~min} \text {; and } 2 \text { min at } 72^{\circ} \mathrm{C}\end{array}$ \\
\hline $\begin{array}{l}\text { IS900 } \\
413 \mathrm{bp} \text { outer }\end{array}$ & $\begin{array}{l}\text { 5'-GAAGGGTGTTCGGGGCCGTCGCTTAGG-3' } \\
\text { 5'-GGCGTTGAGGTCGATCGCCCACGTGAC-3' }\end{array}$ & $\begin{array}{l}95^{\circ} \mathrm{C} \text { for } 15 \mathrm{~min} ; 40 \text { cycles of } 94^{\circ} \mathrm{C} \text { for } 1 \mathrm{~min}, 58^{\circ} \mathrm{C} \text { for } 1 \\
\min , 72^{\circ} \mathrm{C} \text { for } 3 \mathrm{~min} \text {; and } 72^{\circ} \mathrm{C} \text { for } 2 \mathrm{~min}\end{array}$ \\
\hline $\begin{array}{l}\text { IS900 } \\
328 \text { bp nested }\end{array}$ & $\begin{array}{l}\text { 5'-CAGGGACGTCGGGTATGGCTTTCA-3' } \\
\text { 5'-CGTCACCGCCGCAATCAACTCCAG-3' }\end{array}$ & $\begin{array}{l}95^{\circ} \mathrm{C} \text { for } 15 \mathrm{~min} ; 30 \text { cycles of } 94^{\circ} \mathrm{C} \text { for } 1 \mathrm{~min}, 55^{\circ} \mathrm{C} \text { for } 1 \\
\min , 72^{\circ} \mathrm{C} \text { for } 3 \mathrm{~min} \text {; and } 72^{\circ} \mathrm{C} \text { for } 2 \mathrm{~min}\end{array}$ \\
\hline $\begin{array}{l}\text { IS900 } \\
193 \text { bp outer }\end{array}$ & $\begin{array}{l}\text { 5'-GCCCGGATGCGCCACGACTT-3' } \\
\text { 5'-GCGCGGCACGGCTCTTGTTGTA-3' }\end{array}$ & $\begin{array}{l}95^{\circ} \mathrm{C} \text { for } 15 \mathrm{~min} ; 40 \text { cycles of } 94^{\circ} \mathrm{C} \text { for } 1 \mathrm{~min}, 68^{\circ} \mathrm{C} \text { for } 1 \\
\min , 72^{\circ} \mathrm{C} \text { for } 30 \mathrm{sec} \text {; and } 2 \text { min at } 72^{\circ} \mathrm{C}\end{array}$ \\
\hline $\begin{array}{l}\text { IS900 } \\
155 \mathrm{bp} \text { nested }\end{array}$ & $\begin{array}{l}\text { 5'-GCGCCACGACTTGCAGCCTCTG-3' } \\
\text { 5'-CGCGTTCCAGCGCCGAAAGTATT-3' }\end{array}$ & $\begin{array}{l}95^{\circ} \mathrm{C} \text { for } 15 \mathrm{~min} ; 30 \text { cycles of } 94^{\circ} \mathrm{C} \text { for } 1 \mathrm{~min}, 68^{\circ} \mathrm{C} \text { for } 30 \\
\mathrm{sec}, 72^{\circ} \mathrm{C} \text { for } 30 \mathrm{sec} \text {; and } 2 \mathrm{~min} \text { at } 72^{\circ} \mathrm{C}\end{array}$ \\
\hline
\end{tabular}

nested systems was compared using template DNA from Map positive bovine and non-gut control tissue samples.

In examining Crohn's disease tissue, effective DNA isolation was checked in each sample by PCR amplification of the 133 bp APC sequence. When effective DNA isolation was confirmed in each Crohn's sample, nested PCR detecting the 155 bp fragment of IS900 was performed using template DNA from both microdissected granulomas and whole tissue sections. PCR was performed twice and had a minimum ratio of 2:1 Crohn's tissue: disease control tissue per run.

All reactions were carried out on an Eppendorf Mastercycler gradient thermocycler (Eppendorf, Hamburg, Germany), and using Qiagen HotStarTaq Master Mix kit reagents (Qiagen). The reaction mix for the first round of PCR contained primer $\operatorname{mix}$ at $0.5-1 \mu \mathrm{M}$ final concentration, and $10 \mu \mathrm{l}$ DNA isolate. The reaction mix for the second round of PCR, nested or nonnested, contained $1 \mu \mathrm{l}$ of the primary PCR product. Aliquots of completed PCR reactions were run on a $2 \%$ agarose gel using SYBR Green 1 nucleic acid stain (Amresco Inc, Ohio, USA) as per manufacturer's instructions, and visualised at $302 \mathrm{~nm}$ with a transilluminator. New primers were designed using Lasergene Primerselect software (DNASTAR Inc, Madison, WI, USA).

\section{Methods used to prevent contamination}

Mixing of PCR reagents was done in a separate laboratory area from that where template DNA was added. Before addition of template DNA, each reaction mix was first placed in ultraviolet light of wavelength $254 \mathrm{~nm}$ and intensity $30000 \mu \mathrm{J} / \mathrm{cm}^{2}$ for four minutes to destroy any contaminating DNA. Negative controls containing no DNA were used in every PCR reaction. Filter plugged pipette tips were used throughout the entire process.

\section{Confirmation of PCR product amplification}

Unused PCR product was purified in a centrifuge column with the Qiaquick PCR purification kit (Qiagen). The purified DNA was precipitated with ethanol and DNA sequence analysis was performed (MWG AG Biotech, Ebersberg, Germany). Product specificity was confirmed by comparison with the published $M$ paratuberculosis IS900A sequence on the EMBL GenBank DNA sequence database, accession number X16293. The nested PCR product spans nucleotides 583-737 (155 bp) of this sequence.

\section{RESULTS}

\section{Amplicon size affects reliability of PCR from formalin fixed tissue}

To examine how amplicon size affected PCR amplification of target genes from formalin fixed DNA, primer pairs amplifying larger and smaller fragments of the human $A P C$ gene were used (fig 2). In 16 test samples of template DNA, the larger $A P C$ gene fragment could only be detected in four of eight whole tissue sections and one of eight microdissected granulomas. The smaller APC gene sequence amplified consistently in all of the same samples (16 of 16). This demonstrated that amplification of smaller target sequences from formalin fixed tissue was more reliable. This was as expected given that formalin fixation results in widespread nucleic acid and protein cross linkage, with the result that DNA extracted from formalin fixed tissues is fragmented into sequences of variable size. ${ }^{26}$ It has been reported that because DNA is fragmented amplification of longer sequences ( $>250 \mathrm{bp}$ ) is inconsistent in this type of specimen. ${ }^{27}{ }^{28}$ The effect was exaggerated in microdissected samples because the number of cells per sample was comparatively small $\left(10^{2}-10^{3}\right.$ compared with $10^{6}-10^{7}$ in whole tissue sections), with proportionally less chance of finding the target sequence intact.

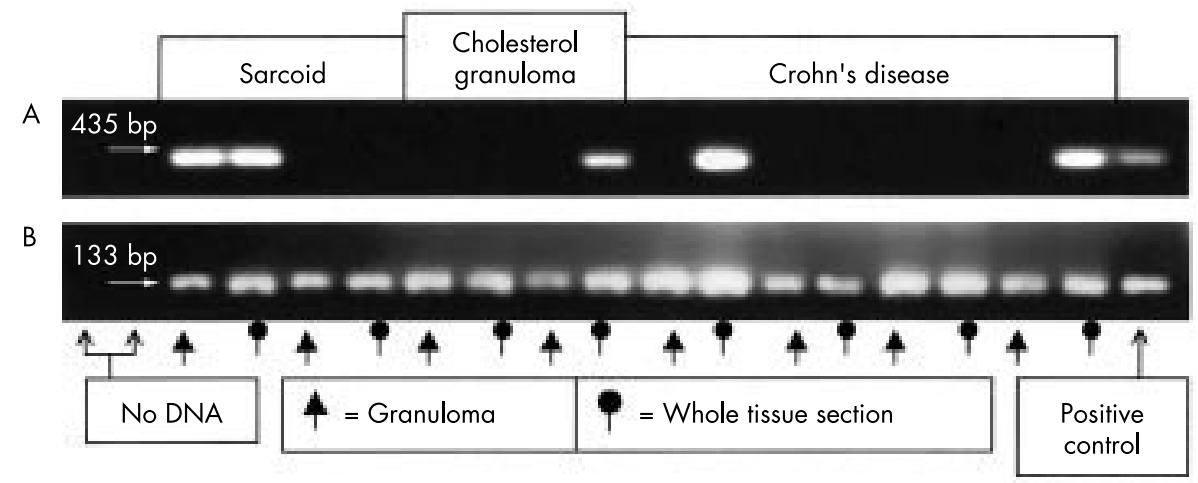

Figure 2 Differences in target fragment length affects ability to reliably amplify sequences in formalin fixed tissue. (A) PCR amplification of a $435 \mathrm{bp}$ target sequence of the APC gene was positive in one of eight microdissected granulomas and four of eight whole tissue sections; (B) PCR of a shorter $133 \mathrm{bp}$ target sequence of the APC gene was positive in all (16 of 16) of the same samples. 

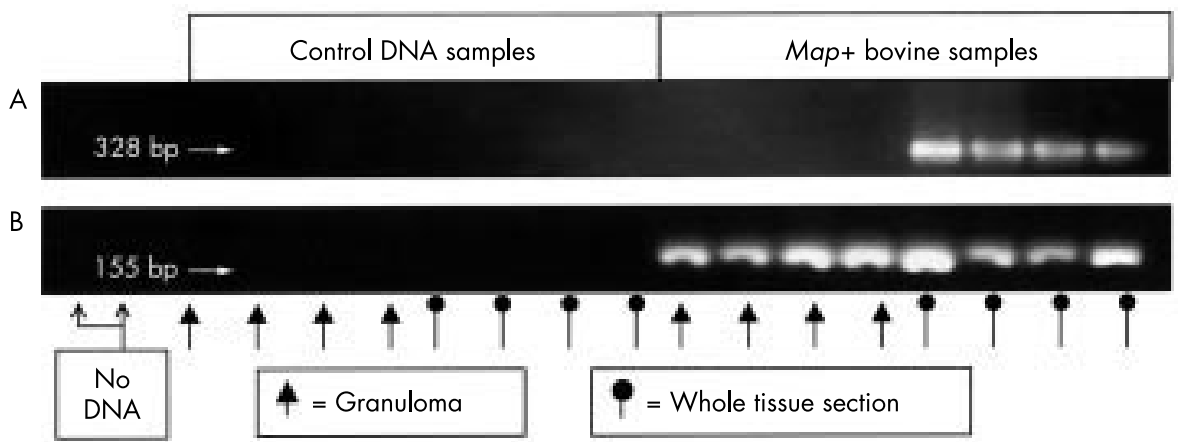

Figure 3 Reliable detection of Map DNA using nested PCR. (A) Nested PCR targeting a $413 \mathrm{bp}$ and then a 328bp sequence of IS900. Gel electrophoresis of the $328 \mathrm{bp}$ nested product was positive in Map positive bovine tissue sections but not in bovine microdissected granulomas. Control samples from microdissected granulomas and whole tissue sections of cholesterol granuloma of breast and mediastinal sarcoidosis were negative; (B) nested PCR targeting a 193bp and then a 155bp sequence of IS900 in the same samples. Gel electrophoresis of the 155bp nested product was positive in Map positive bovine tissue sections and bovine microdissected granulomas, and negative in control samples.

\section{Detection of Map DNA in microdissected granulomas} The ability to reliably amplify target sequences of $M$ paratuberculosis was similarly affected by fragment size (fig 3). Nested PCR amplifying larger fragments of the Map specific IS900 insertion sequence used previously published primers amplifying a 413 bp primary fragment, ${ }^{25}$ and newly designed primers amplifying a 328 bp nested fragment. In Map culture positive bovine intestine, this nested PCR detected Map in four of four whole tissue sections but did not detect Map in any of four microdissected granulomas. In contrast, when primers were designed to amplify a 193 bp primary and a 155 bp nested IS900 fragments, the smaller 155 bp fragment was detected consistently in all whole tissue sections and also in all microdissected granulomas. This indicated that smaller IS900 sequences should be targeted to permit reliable detection of Map DNA in microdissected granulomas. Disease control samples for this PCR were from microdissected samples and whole tissue sections of cholesterol granuloma of breast and mediastinal node sarcoidosis. These control samples were negative for Map in four of four microdissected granulomas and four of four whole tissue sections.

\section{Detection of M paratuberculosis in Crohn's disease tissues}

Subepithelial granulomas were isolated using LCM from 15 surgical Crohn's disease specimens. All microdissected granulomas and whole tissue sections were positive for the smaller fragment of the APC gene, indicating that amplifiable DNA was isolated effectively from each sample. Using nested PCR to detect the 155 bp IS900 sequence, Map DNA was detected in microdissected granulomas in 6 of 15 cases, and in whole tissue sections in 3 of 15 cases (fig 4). The PCR system (primary + nested) was performed twice with $>93 \%$ concordance between results-in one granuloma Map was detected in only one of the two PCR runs. All three positive whole tissue sections had Map positive corresponding granulomas. Importantly, the other three Map positive granulomas were negative on PCR examination of whole tissue sections. This indicated that LCM isolation of granulomas allowed detection of Map microorganisms that were missed by examination of whole tissue sections. Microdissected granulomas and whole tissue sections of cholesterol granuloma of breast and mediastinal node sarcoidosis were negative throughout, as were PCR tubes where no template DNA was added. All 10 specimens (table 1) of microdissected non-Crohn's bowel granulomas were also Map negative, and Map was detected in only one of ten corresponding whole tissue sections examined. DNA sequencing confirmed that detected 155 bp PCR products were 100\% identical to the targeted IS900 fragment.

\section{DISCUSSION}

The hypothesis that an occult infectious micro-organism is the aetiological agent in Crohn's disease has been neither proved nor disproved conclusively. Attempts to detect Map in Crohn's tissue using PCR are numerous and contradictory, with more than 12 negative and more than eight positive reports. ${ }^{89}$ Previously reported positive results may have been attributable, in part, to contaminating luminal Map micro-organisms, the significance of which is uncertain. Use of the laser capture microscope to precisely isolate subepithelial granulomas permitted analysis of genomic DNA solely from this target area, and thus prevented contamination from the lumen. Granulomas were targeted, as they were the most likely repositories of occult mycobacteria. ${ }^{10}$ In 6 of 15 cases of Crohn's disease examined, Map DNA was detected within microdissected granulomas.

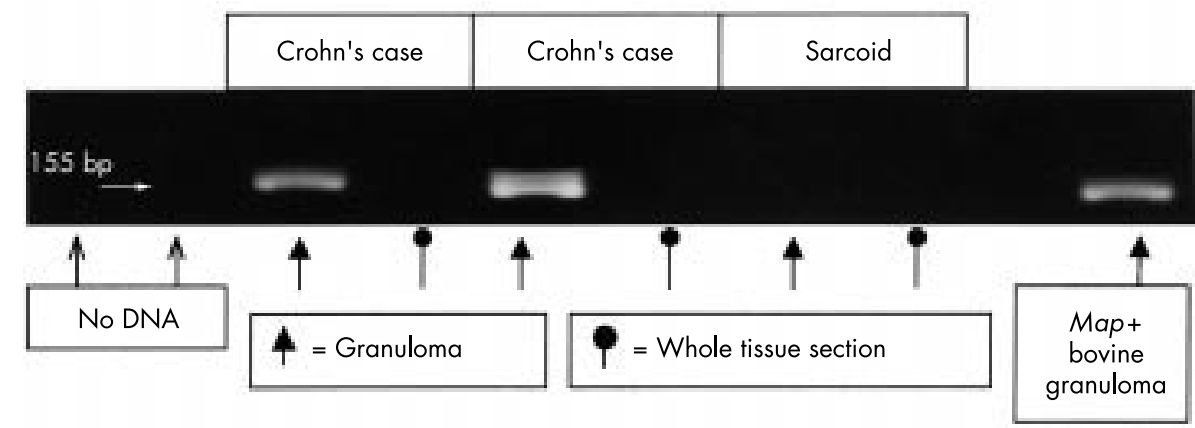

Figure 4 Detection of Map DNA in Crohn's disease microdissected granulomas. Two representative cases of Crohn's are shown (each with Map positive microdissected granuloma and Map negative whole tissue section) along with a disease control (sarcoid) and a positive control (Map positive bovine granuloma). 
In this study archival formalin fixed tissue was used to permit accurate recognition of granulomas. However, the formalin fixation process results in fragmentation of extracted DNA, ${ }^{26}$ and this leads to difficulty in PCR amplification of target sequences longer than 250 bp. ${ }^{27}{ }^{28}$ This was overcome in our study by targeting smaller gene sequences. The increased reliability of this strategy was seen with PCR of both the APC "housekeeping" gene and the IS900 sequence. While recent studies suggest that IS900 elements may be found in other mycobacterial subspecies in settings not encountered in this study, ${ }^{29}{ }^{30}$ the Map specificity of the IS900 fragment targeted by our new primers was confirmed by sequence homology searches.

Map DNA was detected in 40\% of Crohn's cases where microdissected granulomas were examined, but only half of the granuloma positive cases had corresponding whole tissue sections that were positive for Map. The greater detection rate of Map in LCM isolated granulomas compared with whole tissue sections may have been attributable to better targeting of Map DNA in granulomas-PCR may suffer loss of sensitivity because of the potential dilutional effect of the large quantities of non-target DNA found in whole tissue sections. ${ }^{25}$ The association of Map with the granulomatous form of Crohn's disease has been reported previously with in situ hybridisation using a labelled IS900 fragment, although interestingly Map was not localised to granulomas but to macrophages and myofibroblasts. ${ }^{31}$ When the reliability of the method used to isolate DNA from Gram positive bacteria was assessed, using tissue spiked with cultured Listeria monocytogenes, it was found to be inefficient (data not shown). Therefore it is possible that the Map detection rates may be an underestimate of true incidence. However, as Map is commonly present in cell wall deficient forms in Crohn's patients, ${ }^{4}{ }^{31}$ the PCR detection rate may be a reliable estimate of true incidence.

These findings may partially explain the lack of consensus arising from previous studies. Failure to detect Map in some studies may have been attributable to inefficient amplification of long sequences (>250 bp). ${ }^{19}$ Increased sensitivity of detection of Map DNA with smaller target sequences in Crohn's disease tissue samples has been noted in other studies. ${ }^{21}{ }^{32}$ Other inconsistencies may have arisen where superficial biopsy samples were used, ${ }^{20}{ }^{33-36}$ either because of contamination from the lumen or limited sensitivity associated with fewer granulomas in such samples.

The significance of reliable detection of Map DNA in Crohn's disease tissues remains debateable. The absence of Map in control granulomas and in 9 of 10 control whole tissue sections suggests a positive association with Crohn's disease. However, previous studies have reported a lack of detectable mucosal bacteria in non-IBD control samples. ${ }^{37}{ }^{38}$ Increased detection of Map within the gut wall may be representative of generalised dysregulation of mucosal-bacterial interaction and of increased mucosal permeability. ${ }^{7}$ These DNA fragments may also represent simple transit as cellular debris within macrophages or serve to maintain immune tolerance via the dendritic cell system. ${ }^{39}$ They may also indicate that Map can influence the mucosal cytokine milieu as occurs with commensal bacteria ${ }^{40}$ In this manner Map DNA might have an indirect impact on the pathogenesis of Crohn's disease, and its presence does not require an infectious or transmissible hypothesis.

In conclusion, the results of this study indicate that $M$ paratuberculosis cannot be excluded from having a potential role in the pathogenesis of a subset of cases of Crohn's disease. However, the presence of Map DNA within granulomas does not necessarily imply a direct or simple aetiology with a transmissible agent, and the relation may be more complex and indirect including a modifying effect on the local immune response.

\section{ACKNOWLEDGEMENTS}

The authors would like to acknowledge the assistance of the staff of the central and regional veterinary laboratories in providing the sample of $M$ paratuberculosis infected bovine intestine. The authors are supported in part by the Irish Health Research Board, the Irish Higher Education Authority, the Wellcome Trust, and The European Commission (PROGID: QLKI-2000-00563).

\section{Authors' affiliations}

P Ryan, M W Bennett, S Aarons, J O'Connell, F Shanahan, Department of Medicine, National University of Ireland, Cork, Ireland J K Collins, Department of Microbiology, National University of Ireland G C O'Sullivan, Department of Surgery, National University of Ireland G Lee, Department of Histopathology, Mercy Hospital, Cork, Ireland

\section{REFERENCES}

1 Johne HA, Frothingham L. Dtsch Zeitschr Tiermed Vergl Pathol 1895;21:438.

2 Dalziel TK. Chronic intestinal enteritis. BM 1913;ii:1068-70.

3 Chiodini RJ, Van Kruiningen HJ, Merkal RS, et al. Characteristics of an unclassified Mycobacterium species isolated from patients with Crohn's disease. J Clin Microbiol 1984:20:966-71.

4 Chiodini RJ, Van Kruiningen HJ, Thayer WR, et al. Spheroplastic phase of mycobacteria isolated from patients with Crohn's disease. J Clin Microbiol 1986;24:357-63

5 Chamberlin W, Graham DY, Hulten K, et al. Mycobacterium avium subsp. paratuberculosis as one cause of Crohn's disease. Aliment Pharmacol Ther 2001;15:337-46.

6 Schwartz D, Shafran I, Romero C, et al. Use of short-ferm culture for identification of Mycobacterium avium subsp. paratuberculosis in tissue from Crohn's disease patients. Clin Microbiol Infect 2000;6:303-7.

7 Fiocchi C. Inflammatory bowel disease: etiology and pathogenesis. Gastroenterology 1998;115:182-205

8 Naser S, Shafran I, El-Zaatari F. Mycobacterium avium subsp. paratuberculosis in Crohn's disease is serologically positive. [Letter]. Clin Diag Lab Immunol 1999;6:282.

9 El-Zaatari FA, Naser SA, Hulten K, et al. Characterization of Mycobacterium paratuberculosis p36 antigen and its seroreactivities in Crohn's disease. Curr Microbiol 1999;39:1 15-19.

10 Sanderson JD, Moss MT, Tizard ML, et al. Mycobacterium paratuberculosis DNA in Crohn's disease tissue. Gut 1992;33:890-6.

11 McDonald TT. The hypothesised link between dairy products, Mycobacterium paratuberculosis and Crohn's disease. London: The Dairy Council (UK), February 2001

12 European Commission. Possible links between Crohn's disease and Paratuberculosis. Report of the Scientific Committee on Animal Health and Animal Welfare. (Adopted 21 March 2000). The European Commission.

13 Relman DA. The search for unrecognised pathogens. Science 1999;284: 1308-10.

14 Emmert-Buck MR, Bonner RF, Smith PD, et al. Laser capture microdissection. Science 1996:274:998-1001.

15 Chen TC, Hsieh LL, Ng KF, et al. Absence of APC gene mutation in the mutation cluster region in hepatocellular carcinoma. Cancer Lett $1998 ; 134: 23-8$

16 Green EP, Tizard ML, Moss MT, et al. Sequence and characteristics of IS900, an insertion element identified in a human Crohn's disease isolate of Mycobacterium paratuberculosis. Nucleic Acids Res of Mycobacterium para.

17 Rowbotham DS, Mapstone NP, Trejdosiewicz LK, et al. Mycobacterium paratuberculosis DNA not detected in Crohn's disease tissue by fluorescent polymerase chain reaction. Gut 1995:37:660-7.

18 Fidler HM, Thurrell W, Johnson NM, et al. Specific detection of Mycobacterium paratuberculosis DNA associated with granulomatous tissue in Crohn's disease. Gut 1994;35:506-10.

19 Riggio MP, Gibson J, Lennon A, et al. Search for Mycobacterium paratuberculosis DNA in orofacial granulomatosis and oral Crohn's disease tissue by polymerase chain reaction. Gut 1997;41:646-50.

20 Dumonceau JM, Van Gossum A, Adler M, et al. No Mycobacterium paratuberculosis found in Crohn's disease using polymerase chain reaction. Dig Dis Sci 1996:41:421-6.

21 Erasmus DL, Victor TC, van Eeden PJ, et al. Mycobacterium paratuberculosis and Crohn's disease. [Letter]. Gut 1995;36:942.

22 Ikonomopoulos JA, Gorgoulis VG, Kastrinakis NG, et al. Sensitive differential detection of genetically related mycobacterial pathogens in archival material. Am J Clin Pathol 2000;1 14:940-50.

23 Frank TS, Cook SM. Analysis of paraffin sections of Crohn's disease for Mycobacterium paratuberculosis using polymerase chain reaction. Mod Pathol 1996;9:32-5.

24 Moss MT, Sanderson JD, Tizard ML, et al. Polymerase chain reaction detection of Mycobacterium paratuberculosis and Mycobacterium avium subsp silvaticum in long term cultures from Crohn's disease and control tissues. Gut 1992;33:1209-13.

25 Millar DS, Withey SJ, Tizard ML, et al. Solid-phase hybridization capture of low-abundance target DNA sequences: application to the polymerase chain reaction detection of Mycobacterium paratuberculosis and Mycobacterium avium subsp. silvaticum. Anal Biochem 1995;226:325-30 
26 Goelz SE, Hamilton SR, Vogelstein B. Purification of DNA from formaldehyde fixed and paraffin embedded human tissue. Biochem Biophys Res Commun 1985;130:118-26.

27 Hung J, Kishimoto Y, Sugio K, et al. Allele-specific chromosome $3 p$ deletions occur at an early stage in the pathogenesis of lung carcinoma. JAMA 1995:273:1908.

28 Cawkwell L, Quirke P. Direct multiplex amplification of DNA from a formalin fixed, paraffin wax embedded tissue section. Mol Pathol 2000;53:51-2.

29 Naser SA, Felix J, Liping H, et al. Occurrence of the IS900 gene in Mycobacterium avium complex derived from HIV patients. Mol Cell Probes 1999;13:367-72.

30 Cousins DV, Whittington R, Marsh I, et al. Mycobacteria distinct from Mycobacterium avium subsp. paratuberculosis isolated from the faeces of ruminants possess IS900-like sequences detectable IS900 polymerase chain reaction: implications for diagnosis. Mol Cell Probes 1999; 13:431-42.

31 Hulten K, El-Zimaity HM, Karttunen TJ, et al. Detection of Mycobacterium avium subspecies paratuberculosis in Crohn's diseased tissues by in situ hybridization. Am J Gastroenterol 2001;96:1529-35.

32 Whittington RJ, Reddacliff L, Marsh I, et al. Detection of Mycobacterium avium subsp. paratuberculosis in formalin-fixed paraffin-embedded intestinal tissue by IS900 polymerase chain reaction. Aust Vet J $1999 ; 77: 392-7$
33 Cellier C, De Beenhouwer $\mathrm{H}$, Berger A, et al. Mycobacterium paratuberculosis and Mycobacterium avium subsp. silvaticum DNA cannot be detected by PCR in Crohn's disease tissue. Gastroenterol Clin Biol 1998;22:675-8

34 Chiba M. Fukushima T, Horie $Y$, et al. No Mycobacterium paratuberculosis detected in intestinal tissue, including Peyer's patches and lymph follicles, of Crohn's disease. J Gastroenterol 1998;33:482-7.

35 Clarkston WK, Presti ME, Petersen PF, et al. Role of Mycobacterium paratuberculosis in Crohn's disease: a prospective, controlled study using polymerase chain reaction. Dis Colon Rectum 1998:41:195-9.

36 Al-Shamali M, Khan I, Al-Nakib B, et al. A multiplex polymerase chain reaction assay for the detection of Mycobacterium paratuberculosis DNA in Crohn's disease tissue. Scand J Gastroenterol 1997;32:819-23.

37 Schultsz C, Van Den Berg FM, Ten Kate FW, et al. The intestinal mucus layer from patients with inflammatory bowel disease harbors high numbers of bacteria compared with controls. Gastroenterology 1999:117:1089-97.

38 Swidsinski A, Ladhoff A, Pernthaler A, et al. Mucosal flora in inflammatory bowel disease. Gastroenterology 2002;122:44-54.

39 Banchereau J, Steinman RM. Dendritic cells and the control of immunity. Nature 1998:392:245-52.

40 Hooper LV, Wong MH, Thelin A, et al. Molecular analysis of commensal host-microbial relationships in the intestine. Science 2001;291:881-4.pick;gut.dsbm.f1;0;1

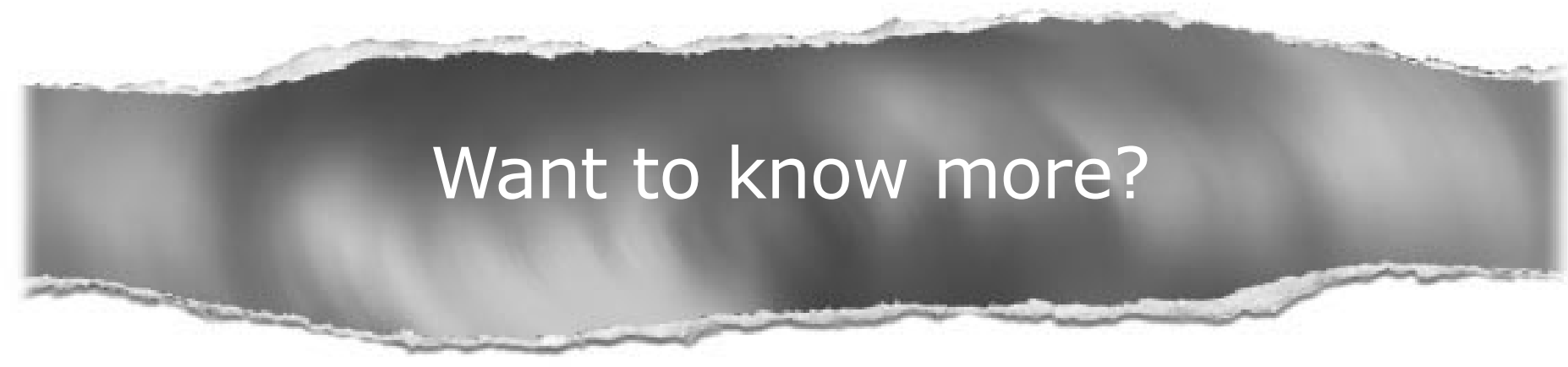

Data supplements

Limited space in printed journals means that interesting data and other material are often edited out of articles; however, limitless cyberspace means that we can include this information online.

Look out for additional tables, references, illustrations.

www.gutjnl.com 